\title{
Canine ovarian dysgerminoma
}

\section{Florencia Sollier Podestá ${ }^{1}$ (b) Daniela Izquierdo Caquias ${ }^{1}$}

${ }^{1}$ Small animal Department, Surgery Area, Veterinary Faculty, Universidad de la República (UDELAR), 18241850, Montevideo, Uruguay. E-mail: florencia.sollier@gmail.com. .Corresponding author.

ABSTRACT: This research aimed to describe a clinical case of ovarian dysgerminoma in a bitch, by showing clinical, ultrasound, surgical and pathological findings. The research also sought to emphasize the importance of establishing an early and definitive diagnosis through histopathology, establishing appropriate protocols for each patient. Ovarian tumors have a low incidence in dogs and cats. Dysgerminomas are a type of ovarian germ cell tumor. They develop in dogs of variable age, that may present clinical signs of hormonal imbalance such as persistent estrus, or pyometra. Prognosis is good in animals that undergo surgery and show no evidence of metastasis. This article presents a clinical case of a 6-year-old English Bulldog with persistent estrus for 2 months, and slightly depressed mental state. Ultrasound revealed the presence of a mass on the left ovary and uterine content. Ovariohysterectomy was performed and the mass was submitted to histopathological exam, which diagnosed an ovarian dysgerminoma.

Key words: ovarian neoplasia, dysgerminoma, canine tumor

Disgerminoma ovariano canino

RESUMO: Neste trabalho descrevem-se caso clínico, achados de ultrassom, cirúrgicos e patológicos de disgerminoma ovárico em cadela. Os tumores ováricos têm baixa incidência em cães e gatos. Nesta categoria estão os tumores das células germinativas, a partir das quais se desenvolvem os disgerminomas. Acomete cadelas de idades variáveis, que podem apresentar sinais clínicos indiciando alterações hormonais, como cio persistente, ou piometra. O prognóstico em animais tratados cirurgicamente, sem evidência de metástase, é bom. Esta pesquisa relata um caso clínico em cadela, raça Bulldog Inglês, de 6 anos de idade, com presença de cio persistente por dois meses. $O$ ultrassom revelou a presença de massa ao nivel do ovário esquerdo e escasso conteúdo uterino. Foi realizada ovariohisterectomia e a peça cirúrgica foi enviada para anatomia patológica, que diagnosticou disgerminoma ovarico. Após a resolução do caso, ressalta-se a importancia do diagnóstico clinico e histopatológico precoce para estabelecer protocolos de tratamento adequados.

Palavras-chave: neoplasias ovaricas, disgerminoma, tumor canino.

Ovarian tumors are infrequent in dogs and cats. The incidence reported in intact bitches is $6.25 \%$ $(0.25-1.2 \%$ of all canine tumors) (KLEIN, 2007). The etiology of ovarian neoplasia in veterinary medicine is not completely known. In humans, gene mutations are risk factors for developing ovarian tumors. Also, the influence of estrogen during continuous cycles in women raises the risk for ovarian tumors. In contrast, pregnancy, lactation and contraceptives seem to be protective factors. These factors have not been fully studied in veterinary medicine (TAYLOR, 2010), but would probably act differently due to species specificities. There are three categories of ovarian tumors based on its cellular origin: epithelial cell, germinal cell and sex cord stromal cells (KLEIN,
2007). Even though there are reports of bilateral ovarian neoplasias (OLIVEIRA et al., 2016), most are unilateral (SFORNA et al., 2003).

Dysgerminomas, which proceed from undifferentiated germ cells, represent $6-12 \%$ of ovarian neoplasias, and $10-20 \%$ of them are malignant in canine (MCENTEE, 2002). This research presents a case of ovarian dysgerminoma in a 6 year old dog, and described clinical, diagnostic and surgical findings.

A 6-year-old English Bulldog was presented for clinical evaluation with a history of persistent estrus for 2 months. In addition to the slightly depressed mental state, the clinical examination evidenced vulvar edema, but no vulvar discharge. 
No abdominal masses were detected on abdominal palpation. No vaginal smear was performed. Blood analysis was performed, in which both the blood biochemistry and the blood count showed values within the physiological ranges (Table 1). The uterine ultrasonography evidenced marked thickness of both horns (1.6 cm in diameter) and slight hypoechoic content and a mass caudal to the left kidney, with 6.2 $\mathrm{cm}$ in diameter, presenting a heterogeneous aspect with hypo- and anechoic cavities, compatible with neoplasia of the ovary (Figure 1). Abdominal lymph nodes were normal in size, aspect and location. Thoracic radiographs were unremarkable.

Ovariohysterectomy was performed according to Fossum technique (MACPHAIL, 2013). The abdominal viscera, adjacent serosal membranes and the lymph nodes were explored and no evidence of visible metastasis was reported. The surgical specimen was inspected and photographed (Figure 2), and submitted to histopathological exam. As postoperative medication, Enrofloxacin was indicated at a dose of 5 $\mathrm{mg} / \mathrm{kg}$ SID for 10 days, Tramadol at a dose of $4 \mathrm{mg}$
/ $\mathrm{kg}$ BID for 2 days, and Dipirone at a dose of $25 \mathrm{mg}$ / $\mathrm{kg}$ BID for 4 days.

Macroscopically, the right ovary did not present particularities; in the left ovary, a mass measuring $5 \times 4 \times 3.5 \mathrm{~cm}$ was observed. It was polylobulated, cream-brown in color and of soft consistency. On the cut surface there was an elevated area $0.5 \mathrm{~cm}$ wide, brownish, while the remainder was cream colored and smooth. Histopathology revealed a non-encapsulated, ill-defined neoformation, composed of lobules separated by strands of connective tissue. Histological evaluation showed lobules composed of cellular cords, the cells arranged tightly in some areas and more loosely in others. Cells were polyhedral with a moderate amount of a clear eosinophilic cytoplasm, with some cells presenting a markedly vacuolar cytoplasm. The nuclei were round to oval, large, with abundant granular chromatin and one to two nucleoli. Three to four mitosis were seen in each field. Tumor cells reached the borders of the piece studied. There was severe congestion and hemorrhagic foci (Figure 3). These findings

Table 1 - Blood tests results (Reference Intervals according to the Oregon State University).

\begin{tabular}{|c|c|c|c|}
\hline Parameter & Value & Unit & Reference interval \\
\hline Hematocrit & 54 & $\%$ & $37-55$ \\
\hline Hemoglobin & 17.5 & $\mathrm{~g} / \mathrm{dL}$ & $12-18$ \\
\hline $\mathrm{RBC}$ & 7.150 & mill./$/ \mu \mathrm{L}$ & $5.5-8.5$ \\
\hline $\mathrm{MCV}$ & 75.5 & $\mathrm{fL}$ & $60-77$ \\
\hline $\mathrm{MCHC}$ & 32.4 & $\mathrm{~g} / \mathrm{dL}$ & $32-36$ \\
\hline M.H.C & 24.5 & $\mathrm{Pg}$ & $19.5-24.5$ \\
\hline W.H.C MHC & 16500 & $/ \mu \mathrm{L}$ & $6000-17000$ \\
\hline NEUTROPHILS & 10725 & $/ \mu \mathrm{L}$ & $3000-11400$ \\
\hline LYMPHOCYTES & 4819 & $/ \mu \mathrm{L}$ & $1000-4800$ \\
\hline MONOCYTES & 478 & $/ \mu \mathrm{L}$ & $150-1350$ \\
\hline EOSINOPHILS & 478 & $/ \mu \mathrm{L}$ & $100-750$ \\
\hline BASOPHILS & 0 & $/ \mu \mathrm{L}$ & RARE \\
\hline PLATELETS & 274 & $/ \mu \mathrm{L}$ & $200-400 \times 10^{3}$ \\
\hline ALT (SGPT) & 46.2 & $\mathrm{UI} / \mathrm{L}$ & $5-65$ \\
\hline FAS (ALP) & 42.5 & $\mathrm{UI} / \mathrm{L}$ & $12-122$ \\
\hline AST (SGOT) & 16.2 & $\mathrm{UI} / \mathrm{L}$ & $16-50$ \\
\hline ALBUMIN & 3.40 & $\mathrm{~g} / \mathrm{dL}$ & $2.3-4.0$ \\
\hline GLOBULIN & 2.53 & $\mathrm{~g} / \mathrm{dL}$ & $1.9-3.6$ \\
\hline TOTAL PROTEIN & 5.93 & $\mathrm{~g} / \mathrm{dL}$ & $6.7-7.6$ \\
\hline TOTAL BILIRUBIN & 0.10 & $\mathrm{mg} / \mathrm{dL}$ & $0.0-0.5$ \\
\hline CHOLESTEROL & 255.4 & $\mathrm{mg} / \mathrm{dL}$ & $150-275$ \\
\hline UREA & 35.8 & $\mathrm{mg} / \mathrm{dL}$ & $21-60$ \\
\hline CREATININE & 1.4 & $\mathrm{mg} / \mathrm{dL}$ & $1.0-2.0$ \\
\hline
\end{tabular}

Ciência Rural, v.50, n.1, 2020. 


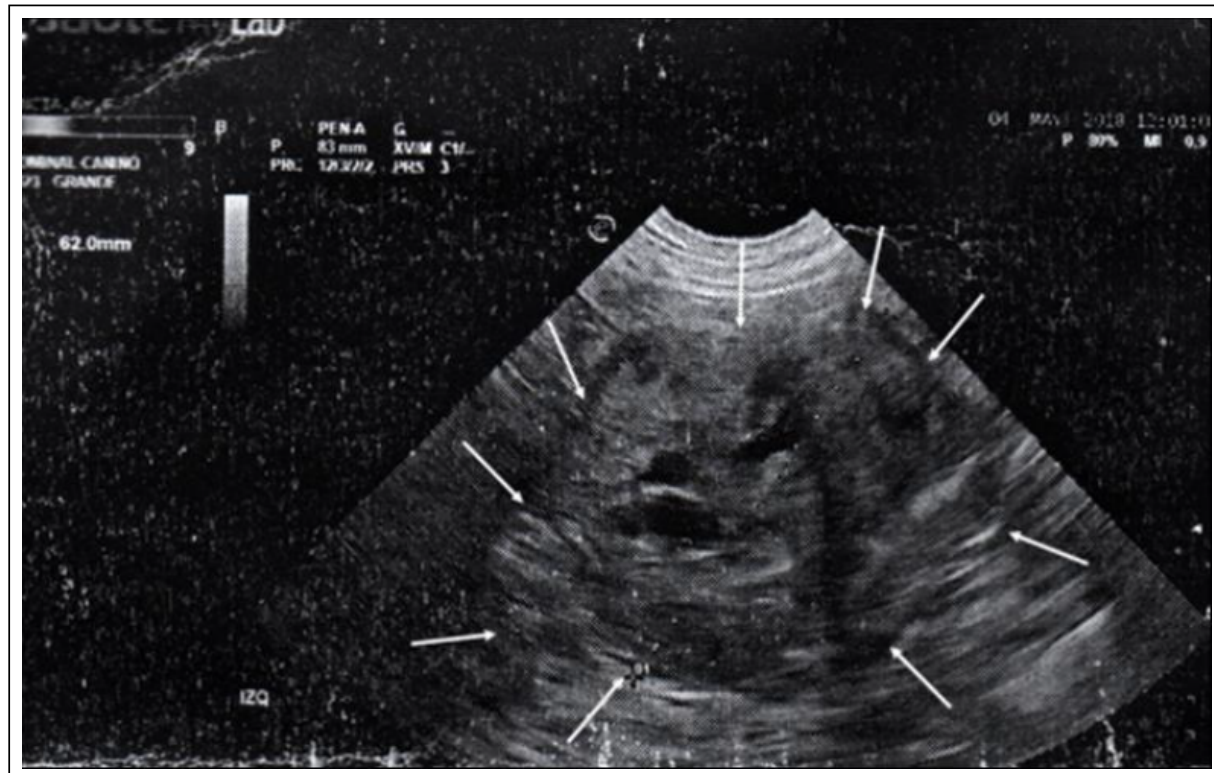

Figure 1 - Ultrasound image. White arrows delimit a mass measuring $6.2 \mathrm{~cm}$ in diameter, compatible with neoplasia of the left ovary.

supported the diagnosis of ovarian dysgerminoma. The patient was treated only with surgery and so far, 9 months after it, evolved positively.

The mean age for dysgerminomas is 10 -12 years, with reports in the range of $2-15$ years of age as in our case (6 years). There is no breed predilection; although, some authors reported a higher incidence in Boxers and bully breeds (MCENTEE, 2002; SFORNA et al., 2003). Dysgerminomas vary in size between $2-30 \mathrm{~cm}$. They grow by expansion and

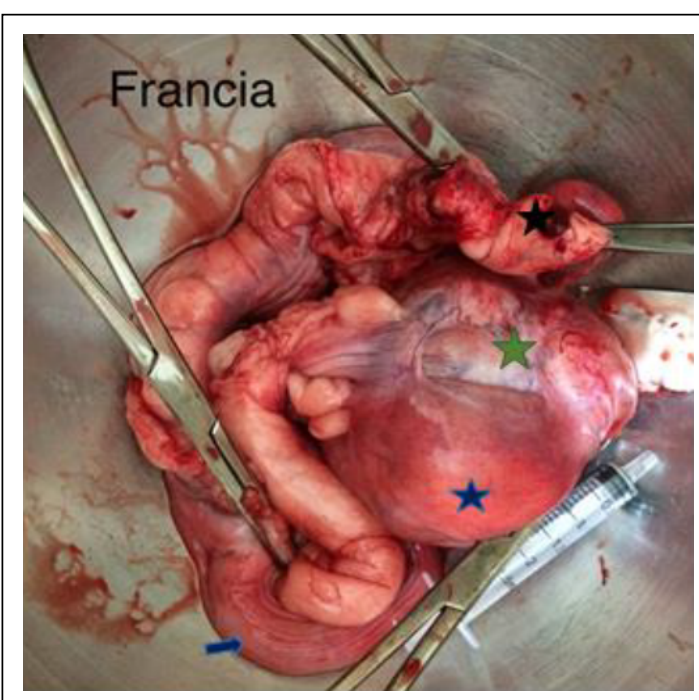

Figure 2 - Macroscopic aspect of excised tissue. Blue arrow: uterus increased in size. Black star: right ovary. Green star: ovarian bursa intact, covers the left ovary. Blue star: the mass is perceived through the ostium of the bursa. 


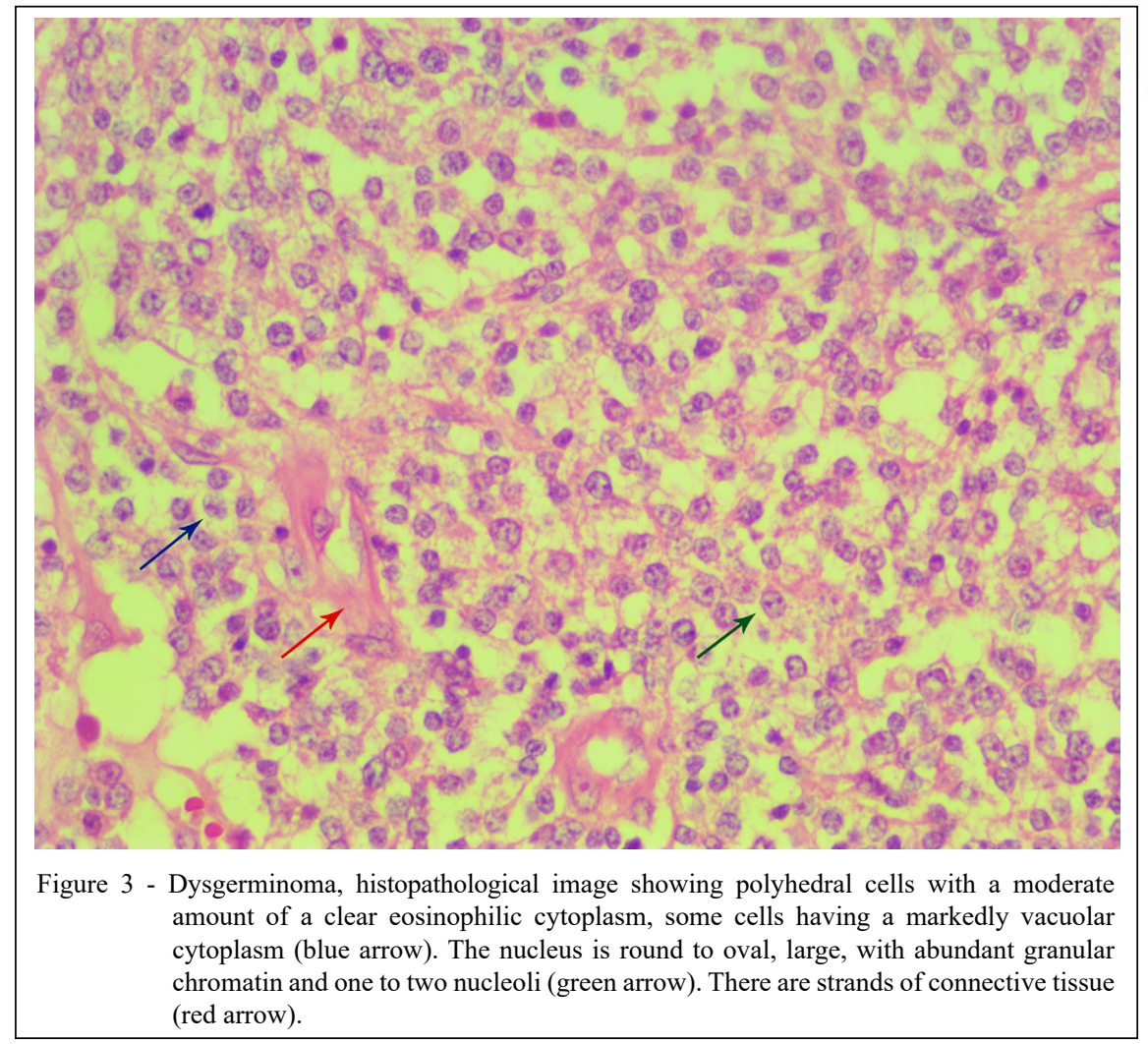

have a reported metastatic rate of $10-30 \%$. Abdominal lymph nodes are the most frequently reported metastatic site, other sites included liver, kidney, omentum, pancreas, adrenal glands (KLEIN, 2007), retroperitoneal lymph nodes (NOVOTNY et al., 2011) and central nervous system (FERNANDEZ et al., 2001).

Clinically, most dysgerminomas appear as a palpable mass of variable size (DIEZ BRU et al., 1998). Ascites is frequently present, and is attributed to metastasis of the peritoneal lymph vessels which cause lymphatic obstruction (DIEZ BRU et al., 1998; KLEIN, 2007). Germ cell tumors can be asymptomatic; there are several reports of ovarian dysgerminomas in dogs with retaining normal estrous cycles. However patients often show hormonal alterations, including irregular estrus, cystic endometrial hyperplasia, and pyometra (DIEZ BRU et al., 1998; KLEIN, 2007; ROLIM et al., 2010), as in the case described here. When ovarian neoplasia is suspected, measuring hormone levels could give useful information about the biologic nature of the tumor. At the moment reports of hormonal production by dysgerminomas are too few both in human and veterinary medicine (ANTONOV et al., 2014).

In the case of the ovarian dysgerminoma reported herein, diagnosis of ovarian tumor was reached based on the history of estrous cycles and ultrasonography, which is the technique of choice to detect ovarian cysts or tumors (DIEZ BRU et al., 1998). Also, ultrasound allows for the detection of uterine anomalies, ascites and lymphadenophaties (KLEIN, 2007; NOVOTNY et al.; 2011; ANTONOV et al. 2014). When there is effusion, abdominocentesis and thoracocentesis should be performed (MCENTEE, 2002), and a cytological analysis requested. Thoracic radiographs should be taken for evidence of metastasis; although, they are usually negative at the time of diagnosis (KLEIN, 2007).

Dysgerminomas should be differentiated from other neoplasias such as lymphosarcomas, solid adenocarcinomas, granulosa cell tumor, theca cell tumor and ovarian teratoma (ROLIM et al., 2010). A definitive diagnosis is reached by histopathology of the tissues extirpated. Specific characteristics of this tumor are the presence of large polyhedral neoplastic cells, similar to primitive germ cells, which form a uniform population of big round cells with scant acidophilic cytoplasm, frequent mitotic figures and focal aggregates of lymphocytes (GREENLEE et al., 1985; KLEIN, 2007). Different types of tumors can be identified by immunohistochemistry. Neoplastic cells in dysgerminomas are positive for vimentin, and

Ciência Rural, v.50, n.1, 2020. 
alkaline phosphatase, and negative for CD3, CD79a, cytokeratin, alpha-fetoprotein, inhibin-a and S-100 (PARK et al., 2009).

Ovariohysterectomy is the treatment of choice (ANTONOV et al., 2014). A careful examination of all serosal surfaces, including omentum and diaphragm, and the excision or biopsy of any other lesion suspected to be metastatic should be done to assess the patient risk (MCENTEE, 2002). Palliative chemotherapy has been cited, but there are no standard protocols established. Radiotherapy is rarely recommended because animals with disease confined to the ovary usually are treated successfully with surgery (KLEIN, 2007). In our patient no adjuvant therapies were needed due to a good evolution. Survival data are few, including survival times of 4 years post surgery. The prognosis for all tumors appears to be the same, in spite of the histopathologic results. The prognosis is good when the tumor is completely resected and poor when there is evidence of metastasis (NOVOTNY et al., 2011; ANTONOV et al., 2014).

This research showed that even though the incidence of ovarian dysgerminoma is low, it should still be considered as a differential diagnosis in dogs with abnormal estrous cycles. In addition, it should be taken into account that it is very often associated with the presence of uterine pathologies, such as pyometra. Vital prognosis improves in direct relation to an early diagnosis, so it is important to know the clinical characteristics and have the necessary tools to reach a diagnosis. After surgical resolution we highlighted the importance of sending the organ (ovary) for histopathology in order to reach a definitive diagnosis and so be able to determine the necessity for any additional therapies.

\section{ACKNOWLEDGMENT}

Mr. Diego Detomasi for the translation of the research.

\section{DECLARATION OF CONFLICT OF INTERESTS}

The authors declare no conflict of interest. The founding sponsors had no role in the design of the study; in the collection, analyses, or interpretation of data; in the writing of the manuscript, and in the decision to publish the results.

\section{AUTHORS' CONTRIBUTIONS}

All authors contributed equally for the conception and writing of the manuscript. All authors critically revised the manuscript and approved of the final version.

\section{REFERENCES}

ANTONOV, A. et al. A clinical case of unilateral ovarian dysgerminoma and pyometra in a bitch. Macedonian Veterinary
Review, v.37, n.2, p.179-183, 2014. Available from: <http://dx.doi. org/10.14432/j.macvetrev.2014.04.013>. Accessed: Jun. 10, 2018. doi: 10.14432/j.macvetrev.2014.04.013.

DIEZ BRU, N. et al. Ultrasonographic appearance of ovarian tumors in 10 dogs. Veterinary Radiology \& Ultrasound, v.39, n.3, p.226-233, 1998. Available from: <https://doi. org/10.1111/j.1740-8261.1998.tb00345.x>. Accessed: Jul. 13 , 2018. doi: 10.1111/j.1740-8261.1998.tb00345.x.

FERNANDEZ, T. et al. Intracranial metastases from an ovarian dysgerminoma in a 2-year-old dog. Journal of the American Animal Hospital Association, v.37, p.553-556, 2001. Available from: <https://doi.org/10.5326/15473317-37-6-553>. Accessed: Jun. 20, 2018. doi: 10.5326/15473317-37-6-553.

GREENLEE, P.G.; PATNAIK, A.K. Canine ovarian tumors of germ cell origin. Veterinary pathology, v.22, p.117-122, 1985. Available from: <https://doi.org/10.1177/030098588502200204>. Accessed: Jun. 10, 2018. doi: 10.1177/030098588502200204.

KLEIN, M.K. Tumors of the female reproductive system. In WITHROW, S.J.; VAIL D.M. Small animal clinical oncology, St. Louis: Saunders Elsevier, 2007, Cap. 25, p. 610-618.

MACPHAIL, C.M. Surgery of the Reproductive and Genital Systems, general principles and techniques, Surgery of the Female Reproductive Tract, In: FOSSUM, T.W.; DEWEY, C.W.; HORN, C.V.; JOHNSTON, A.L.; MACPHAIL, C.M.; RADLINSKY, M.G.; SCHULZ, K.S.; WILLARD, M.D. Small Animal Surgery, 4th ed. ELSEVIER, 2013, Cap. 27, p. 789-793.

MCENTEE, M.C. (2002). Reproductive oncology, Clinical techniques in small animal practice, 17 (3), 133-149. Available from: <https://europepmc.org/abstract/med/12476817>. Accessed: Jul. 1, 2018. doi: 10.1053/svms.2002.34642.

NOVOTNY, R. et al. Ovarian dysgerminoma with retroperitoneal metastases in a bitch: a case report. Veterinarni Medicine, v.56, n.3, p.140-144, 2011. Available from: <http://vri.cz/ docs/vetmed/56-3-140.pdf>. Accesed: Jul., 10, 2018 . doi: 10.17221/3157-VETMED.

OLIVEIRA, A.R.et al. Dysgerminoma and granulosa cell tumor in a bitch. Brazilian Journal of Veterinary Patology, v. 9, n. 1, p. $31-33,2016$. Available from: <http://bjvp.org.br/wp-content/ uploads/2016/03/v9-n1-6.pdf>. Accessed: Jul. 29, 2018.

PARK, J.K.et al. Immunohistochemistry Diagnosis of an ovarian dysgerminoma in one bitch. Reproduction in Domestical Animals, v.44, p.855-858, 2009. Available from: <https://www. ncbi.nlm.nih.gov/pubmed/18992107>. Accessed: Jul. 29, 2018. doi:10.1111/j.1439-0531.2008.01135.x.

ROLIM, V.M.et al. Disgerminoma bilateral e hiperplasia endometrial cística com piometra em cadela. Acta Scientiae Veterinariae, v.38, n.3, p.337-340, 2010. Available from: <http:// www.ufrgs.br/actavet/38-3/921.pdf $>$. Accessed: Nov.7, 2019.

TAYLOR KH. Female Reproductive Tumors. In: Henry CJ y Higginbotham ML (Eds.), Cancer Management in Small Animal Practice. Elsevier, 2010, 268-274.

SFORNA, M. et al. Canine ovarian tumours: a retrospective study of 49 cases. Veterinary Research Communications, v.27, s.1, p.359-361, 2003. Available from: <https://doi.org/10.1023/ B:VERC.0000014180.77684.52>. Accessed: Jul. 4, 2018. doi: 10.1023/B:VERC.0000014180.77684.52.

Ciência Rural, v.50, n.1, 2020. 